\title{
Leptin down-regulates KCC2 activity and controls chloride homeostasis in the neonatal rat hippocampus
}

\author{
Camille Dumon ${ }^{1,3}$, Yasmine Belaidouni', Diabe Diabira', Suzanne M. Appleyard², Gary A. Wayman² \\ and Jean-Luc Gaiarsa ${ }^{1 *}$ (1)
}

\begin{abstract}
The canonical physiological role of leptin is to regulate hunger and satiety acting on specific hypothalamic nuclei. Beyond this key metabolic function; leptin also regulates many aspects of development and functioning of neuronal hippocampal networks throughout life. Here we show that leptin controls chloride homeostasis in the developing rat hippocampus in vitro. The effect of leptin relies on the down-regulation of the potassium/chloride extruder KCC2 activity and is present during a restricted period of postnatal development. This study confirms and extends the role of leptin in the ontogenesis of functional GABAergic inhibition and helps understanding how abnormal levels of leptin may contribute to neurological disorders.
\end{abstract}

Keywords: GABA, KCC2, Chloride homeostasis, Hippocampus, Rat, Leptin, Maternal obesity

\section{Introduction}

Leptin, the product of the obese (ob) gene, is a circulating hormone secreted mainly from the white adipocytes and transported across the blood brain barrier to the hypothalamus to suppress appetite and enhance metabolism in adult [1]. The hypothalamus is not the only central nervous system target for leptin, as a high density of leptin receptors are expressed in other brain areas including the hippocampus where leptin receptors regulate many aspects of synaptic plasticity and cognitive function [2, 3]. A large body of evidence indicates that leptin also acts as an important neurodevelopmental factor during the perinatal period [4-6]. Thus, while plasma leptin levels reflect adiposity in adult rodents, leptin levels surge during the two first postnatal weeks of life regardless of the animal's weight or body fat mass [1]. A similar restricted

\footnotetext{
${ }^{*}$ Correspondence: jean-luc.gaiarsa@inserm.fr

${ }^{1}$ Aix-Marseille Univ UMR 1249, INSERM (Institut National de La Santé et de La Recherche Médicale) Unité 1249, INMED (Institut de Neurobiologie de La Méditerranée), Parc Scientifique de Luminy, Marseille, France Full list of author information is available at the end of the article
}

surge of plasma levels is observed during the last trimester of gestation in human [7]. Along with the leptin surge, leptin receptors are expressed and functional in several brain regions at embryonic and postnatal stages and activation of these receptors promote neuronal networks development [8-14]. Due to the many important physiological and developmental functions of leptin, dysregulation in its availability or signaling has been proposed as causal factors for the occurrence of neurological disorders [15-23].

Abnormalities in GABAergic synaptic transmission are strongly associated with neurological disorders [24, 25]. Therefore, understanding whether and how leptin controls the development and efficacy of the GABAergic transmission is warranted. Leptin deficient $(o b / o b)$ mice exhibit a lower number of GABAergic synapses impinging hypothalamic [26] and hippocampal [12] neurons highlighting the role of leptin in GABAergic synaptogenesis. Likewise, leptin modulates the GABAergic synaptic activity in vitro in the hypothalamus $[27,28]$ and hippocampus $[12,29]$. The homeostasis of intra-neuronal

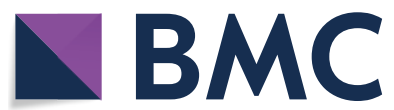

(c) The Author(s) 2020. Open Access This article is licensed under a Creative Commons Attribution 4.0 International License, which permits use, sharing, adaptation, distribution and reproduction in any medium or format, as long as you give appropriate credit to the original author(s) and the source, provide a link to the Creative Commons licence, and indicate if changes were made. The images or other third party material in this article are included in the article's Creative Commons licence, unless indicated otherwise in a credit line to the material. If material is not included in the article's Creative Commons licence and your intended use is not permitted by statutory regulation or exceeds the permitted use, you will need to obtain permission directly from the copyright holder. To view a copy of this licence, visit http://creativecommons.org/licenses/by/4.0/. The Creative Commons Public Domain Dedication waiver (http://creativeco mmons.org/publicdomain/zero/1.0/) applies to the data made available in this article, unless otherwise stated in a credit line to the data. 
$\mathrm{Cl}^{-}$concentration $\left(\left[\mathrm{Cl}^{-}\right]_{\mathrm{i}}\right)$ is an essential determinant of GABA functioning and alterations in $\left[\mathrm{Cl}^{-}\right]_{\mathrm{i}}$ is implicated in the etiology of numerous neurological and psychiatric disorders [30-32]. In a previous study, we reported that the absence of leptin signaling accelerates the ontogenesis of functional GABAergic inhibition in the newborn mice hippocampus in vivo [13]. In the present study we show that leptin acts directly on hippocampal neurons to control $\mathrm{Cl}^{-}$homeostasis and the activity of the $\mathrm{K}^{+}-\mathrm{Cl}^{-}$ co-transporter $\mathrm{KCC} 2$ in the rat hippocampus during a restricted developmental window.

\section{Materials and methods}

All animal procedures were carried out in accordance with the European Union Directive of 22 September $(2010 / 63 / \mathrm{EU})$. The protocol was approved by the INSERM Local committee (Number 0287.01, delivered by the French Ministry of Education and Research). Experiments were performed on both male and female postnatal day (P) 1 to 10 Wistar rats. Animals were housed in a temperature-controlled environment with a 12 light/dark cycle and free access to food and water.

\section{Hippocampal slice preparation}

Brains were removed and immersed into ice-cold $\left(2-4{ }^{\circ} \mathrm{C}\right)$ artificial cerebrospinal fluid (ACSF) with the following composition (in $\mathrm{mM}$ ): $126 \mathrm{NaCl}, 3.5 \mathrm{KCl}, 2 \mathrm{CaCl}_{2}$, $1.3 \mathrm{MgCl}_{2}, 1.2 \mathrm{NaH}_{2} \mathrm{PO}_{4}, 25 \mathrm{NaHCO}_{3}$ and 11 glucose, $\mathrm{pH}$ 7.4 equilibrated with $95 \% \mathrm{O}_{2}$ and $5 \% \mathrm{CO}_{2}$. Hippocampal slices (600 $\mu \mathrm{m}$ thick) were cut with a Mcllwain tissue chopper (Campden Instruments Ltd.) and kept in ACSF at room temperature $\left(25^{\circ} \mathrm{C}\right)$ for at least one hour before recording. Slices were then transferred to a submerged recording chamber perfused with oxygenated $\left(95 \% \mathrm{O}_{2}\right.$ and $\left.5 \% \mathrm{CO}_{2}\right) \operatorname{ACSF}(3 \mathrm{ml} / \mathrm{min})$ at $34{ }^{\circ} \mathrm{C}$.

\section{Electrophysiological recordings}

Perforated patch-clamp recordings were made from CA3 pyramidal neurons. The pipettes (4-7 M $\Omega$ ) were tip filled with an internal solution of $150 \mathrm{mM} \mathrm{KCl}$ and $10 \mathrm{mM}$ HEPES, ( $\mathrm{pH}$ adjusted to 7.2 with Tris-OH) and then backfilled with the same solution containing gramicidin A $(50 \mu \mathrm{g} / \mathrm{ml}$, diluted from a stock solution of $50 \mathrm{mg} / \mathrm{ml}$ in DMSO). Data were acquired with an axopatch 200B amplifier (Molecular Devices LLC, San Jose, USA). A stimulating bipolar tungsten electrode was placed in the CA3 stratum radiatum to evoke $\mathrm{GABA}_{\mathrm{A}}$ receptormediated postsynaptic currents $\left(\mathrm{eGABA}_{\mathrm{A}}-\mathrm{PSCs}\right)$ at a frequency of $0.01 \mathrm{~Hz}$ in the presence of glutamatergic receptor antagonists (NBQX $5 \mu \mathrm{M}$ and D-APV $40 \mu \mathrm{M}$ ). After the access resistance had dropped to 40-80 $\mathrm{M} \Omega$ and stabilized (15-30 $\mathrm{min}$ ), we varied the starting holding potential $(-70 \mathrm{mV})$ in increasing and decreasing steps of $10 \mathrm{mV}$ and measured the peak amplitude of averaged $\mathrm{eGABA}_{\mathrm{A}}-\mathrm{PSCs}$ ( 3 single sweeps) to construct a current-voltage relationship. Leptin was applied for $20 \mathrm{~min}$ and a second current-voltage relationship was conducted. Measurements were not corrected for the liquid junction potentials. A linear regression was used to calculate the best-fit line of the voltage dependence of the synaptic currents. Spontaneous rupture into whole-cell was evidenced by large inward synaptic currents due to $\mathrm{E}_{\mathrm{Cl}}$ of $0 \mathrm{mV}$.

Loose cell attached patch clamp recordings of action potential firing were performed from CA3 pyramidal neurons in the voltage-clamp mode at pipette potential of $0 \mathrm{mV}$ using an axopatch 200B (Molecular Devices LLC, San Jose, USA). The glass electrodes (4-7 M $\Omega$ ) filled with an internal solution of $150 \mathrm{mM} \mathrm{KCl}$ and $10 \mathrm{mM}$ HEPES ( $\mathrm{pH}$ adjusted to 7.2 with Tris-OH). After a baseline period of at least $10 \mathrm{~min}$ in the presence of NBQX $(5 \mu \mathrm{M})$ and D-APV $(40 \mu \mathrm{M})$, Leptin was bath applied for $20 \mathrm{~min}$. The effect of leptin was quantified as the mean frequency of action potential at the end of the leptin application (15-20 $\mathrm{min})$ versus baseline frequency $(-10-0 \mathrm{~min})$.

Evoked synaptic activity and spontaneous action potentials were recorded with Axoscope software version 8.1 (Molecular Devices LLC, San Jose, USA) and analyzed offline with Mini Analysis Program version 6.0 (Synaptosoft).

\section{Drugs}

The following reagents were purchased from the indicated sources: 1,2,3,4-tetrahydro-6-nitro-2,3-dioxobenzo [f]quinoxaline-7-sulfonamide (NBQX) and D-2-amino-5-phospho-valeric acid (D-APV) from the Molecular, Cellular, and Genomic Neuroscience Research Branch (MCGNRB) of the National Institute of Mental Health (NIMH, Bethesda, MD, USA). Leptin and VU0463271from Tocris Cookson (Bristol, UK). Bumetanide and Gabazine from Sigma (St Louis, MN, USA).

\section{Statistics}

Statistical analyses were conducted with GraphPad Prism (GraphPad software 5.01). Shapiro-Wilk normality test was used to determine the normality of distributions. $P<0.05$ was considered significant for this and all subsequent tests. Our data displaying non-normal distribution, we used a Two-tailed Mann-Whitney $U$ test for comparison between two independent groups, and a Two-tailed Wilcoxon matched-pairs signed rank test to compare paired data. To ensure the consistency and reproducibility of our results, we conducted repeated trials in different acute hippocampal slices prepared from at least three different animals for each experimental condition. All 
data are expressed as mean \pm standard error to the mean (S.E.M.). In the figures, box plots represent the 1 st and 3rd quartiles; whiskers show data range; horizontal lines show the median.

\section{Results}

Leptin controls chloride homeostasis in vitro

Our first aim was to determine whether leptin directly acts on hippocampal cells to control $\mathrm{Cl}^{-}$homeostasis in the neonatal rat. We used acute postnatal (P) day 5 rat hippocampal slices and stimulated presynaptic GABAergic neurons while gramicidin perforated patch-clamp recordings were made from CA3 pyramidal neurons in the presence of the glutamatergic receptor blockers NBQX $(5 \mu \mathrm{M})$ and D-APV $(40 \mu \mathrm{M})$.
$\mathrm{GABA}_{\mathrm{A}}$ receptor-mediated postsynaptic currents $\left(\mathrm{eGABA} \mathrm{A}_{\mathrm{A}}\right.$-PSCs) were evoked at different holding potentials, before and during the application of leptin (100 $\mathrm{nM}, 20 \mathrm{~min}$ ), to determine the impact of the adipocyte hormone on their reversal potential $\left(\mathrm{E}_{\mathrm{GABA}}\right)$. We found that leptin induced an average depolarizing shift of $\mathrm{E}_{G \mathrm{GBA}}\left(\Delta \mathrm{E}_{\mathrm{GABA}}\right)$ of $5.4 \pm 1.7 \mathrm{mV}$ (from - 48.2 \pm 2.8 to $-42.8 \pm 3.7 \mathrm{mV}, \mathrm{n}=10, \mathrm{z}=-2.5, p=0.005$, Fig. 1a1, b). In control experiments in which leptin was omitted $\mathrm{E}_{\mathrm{GABA}}$ did not change over the same recording duration (from $-45.6 \pm 3.8$ to $-45.2 \pm 3.8 \mathrm{mV}, \mathrm{n}=8, \mathrm{z}=-1.2$, $p=0.21, \Delta \mathrm{E}_{\mathrm{GABA}}=1.3 \pm 0.5 \mathrm{mV}, \mathrm{U}=16.5, p=0.03$ vs leptin $100 \mathrm{nM}$ response, Fig. 1a2, b). Leptin applied at a concentration of $20 \mathrm{nM}$ for $20 \mathrm{~min}$ had no effect on $\mathrm{E}_{\mathrm{GABA}}$ (from $-53.6 \pm 2.4$ to $-54.8 \pm 3.1 \mathrm{mV}, \mathrm{n}=6, \mathrm{z}=-1.5$,

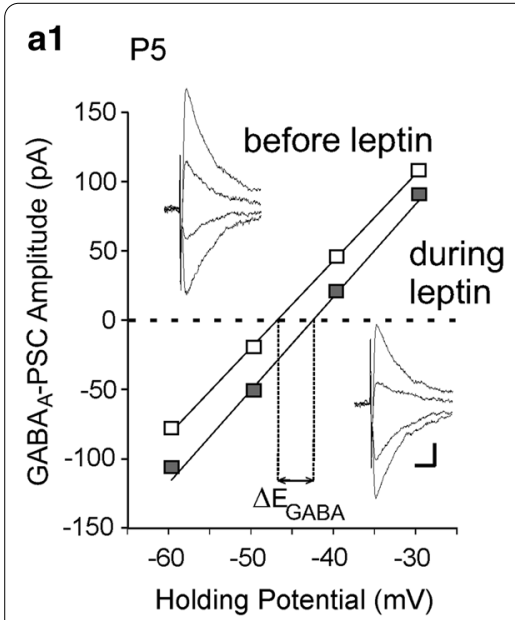

C

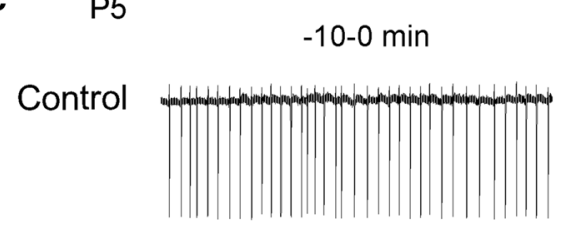

Leptin

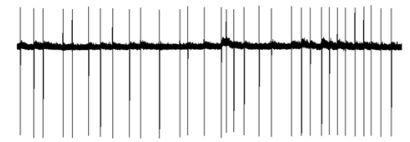

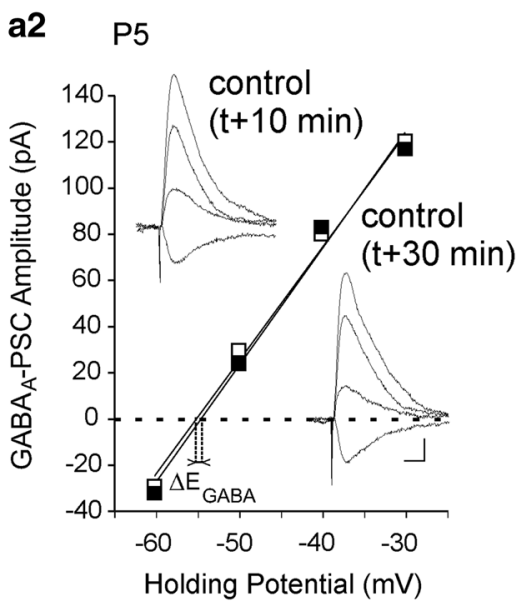

$15-20 \min$
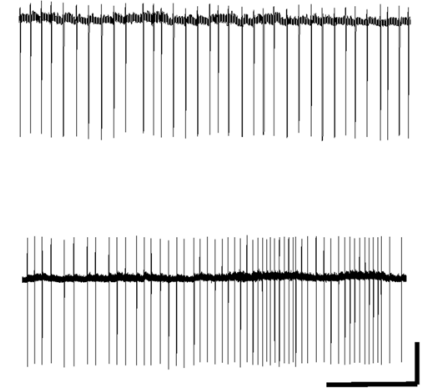

b

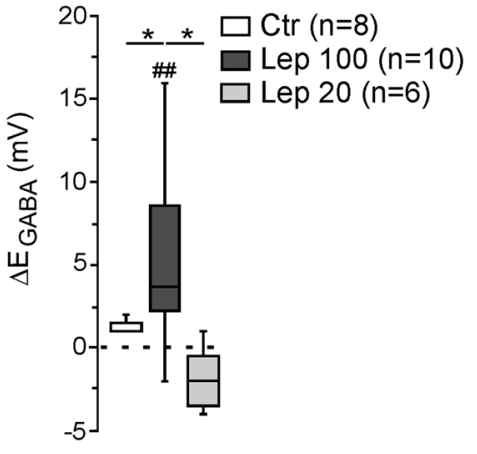

d $\quad$ P5

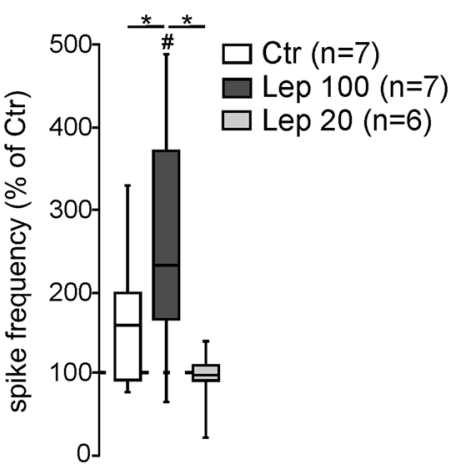

Fig. 1 Leptin controls chloride homeostasis in rat hippocampal slices. a Current-voltage (I-V) relationships for evoked GABAergic synaptic currents before and during leptin application (100 nM, $20 \mathrm{~min}$ ) a1 and in control experiments a2 during which neurons were recorded following the same protocol but leptin was omitted. The intercepts of the linear regression of the I-V curves was used to calculate $\mathrm{E}_{\mathrm{GABA}}$ changes induced by leptin $\left(\triangle \mathrm{E}_{\mathrm{GABA}}\right)$. Insets depict the GABAergic synaptic currents. Scale bars, $10 \mathrm{~ms}, 20 \mathrm{pA}$. b Box plots of $\triangle \mathrm{E}_{\mathrm{GABA}}$ induced by leptin $100 \mathrm{and} 20 \mathrm{nM}$ applied during $20 \mathrm{~min}$. In control experiments (Ctr), neurons were recorded following the same protocol in the absence of leptin. $\mathbf{c}$ Loose patch recordings of CA3 pyramidal neurons on acute hippocampal slices before (- 10-0 min) and during (15-20 min) the application of leptin (100 nM, $20 \mathrm{~min}$ ) and in control experiment, during which neurons recorded following the same protocol in the absence of leptin. Scale bar, 2 min, 50pA. $\mathbf{d}$ Box plots of leptin action on spike activity in the indicated conditions. ${ }^{\# \#} \mathrm{P}<0.01$ when compared to pre-leptin values, two-tailed Wilcoxon paired test. ${ }^{*} \mathrm{P}<0.05$ when compared to leptin experiments, two-tailed Mann Whitney test 
$p=0.5, \Delta \mathrm{E}_{\mathrm{GABA}}=-0.5 \pm 1.6 \mathrm{mV}, \mathrm{U}=11, p=0.09$ vs control experiment, Fig. 1b). We next determined whether the depolarizing shift of $\mathrm{E}_{\mathrm{GABA}}$ induced by leptin was associated with increased neuronal excitation. To this end we recorded action potentials in loose patch mode in the presence of NBQX $(5 \mu \mathrm{M})$ and D-APV $(40 \mu \mathrm{M})$. After a baseline period (10 $\mathrm{min})$, leptin $(100 \mathrm{nM})$ was added to the perfusion medium for $20 \mathrm{~min}$. We assessed the effect of leptin on action potential firing at the end of the leptin application (15-20 $\mathrm{min}$ ) versus the baseline period (-10-0 min, Fig. 1c). Leptin led to a significant increase in the frequency of action potentials (from $0.46 \pm 0.14 \mathrm{~Hz}$ to $1.02 \pm 0.32 \mathrm{~Hz}, \mathrm{n}=7, \mathrm{z}=-2.1, p=0.03$, Fig. $1 \mathrm{c}$, d). In interleaved control experiments in which leptin was omitted the spike firing remained constant (from $0.32 \pm 0.12$ to $0.43 \pm 0.16 \mathrm{~Hz}, \mathrm{n}=7, \mathrm{z}=-1.1, p=0.29 \mathrm{vs}$ baseline and $\mathrm{U}=16, p=0.04$ vs leptin $100 \mathrm{nM}$ response, Fig. 1c, d). In agreement with the lack of effect of leptin at $20 \mathrm{nM}$ on $\mathrm{E}_{\mathrm{GABA}}$ (Fig. 1b), bath applied leptin at the same concentration ( $20 \mathrm{nM}, 20 \mathrm{~min}$ ) had no effect on the firing frequency of CA3 pyramidal neurons (from $0.47 \pm 0.14$ to $0.44 \pm 0.16 \mathrm{~Hz}, \mathrm{n}=6, \mathrm{z}=-0.5, p=0.68$ vs baseline and $\mathrm{U}=17, p=0.12$ vs control experiment, Fig. 1b). Altogether these data show that bath applied leptin shifts $\mathrm{E}_{\mathrm{GABA}}$ towards depolarizing values and increases the neuronal excitation of P5 CA3 pyramidal neurons on rat hippocampal slices.

\section{Leptin controls $\mathrm{KCC} 2$ activity in vitro}

Chloride homeostasis and the strength of $\mathrm{GABA}_{\mathrm{A}}$-mediated synaptic inhibition are mainly controlled by the activity of two cation-chloride cotransporters: the $\mathrm{Na}^{+}-\mathrm{K}^{+}-2 \mathrm{Cl}^{-}$(NKCC1) co-transporter that accumulates $\mathrm{Cl}^{-}$intracellularly and the $\mathrm{K}^{+}-\mathrm{Cl}^{-}(\mathrm{KCC} 2)$ co-transporter that lowers intracellular $\mathrm{Cl}^{-}$concentration $[33,34]$. We therefore asked whether leptin acts on $\mathrm{KCC} 2$ and/or NKCC1 activity. We found that the diuretic bumetanide at a concentration of $100 \mu \mathrm{M}$, to block both NKCC1 and KCC2 had no effect on $\mathrm{E}_{\mathrm{GABA}}$ (from $-51.4 \pm 2.9(\mathrm{n}=20)$ to $-55.6 \pm 4.2 \mathrm{mV},(\mathrm{n}=15)$, $\mathrm{U}=135, p=0.6$, Fig. 2b) but prevented the depolarizing shift of $\mathrm{E}_{\mathrm{GABA}}$ induced by leptin $(100 \mathrm{nM}, 20 \mathrm{~min})$ (from $-54.7 \pm 4.4$ to $-54.6 \pm 5.7 \mathrm{mV}, \mathrm{n}=10, \mathrm{z}=-0.02$, $p=0.85, \Delta \mathrm{E}_{\mathrm{GABA}}=-0.1 \pm 2.0 \mathrm{mV}, \mathrm{U}=22.5, p=0.03$ vs leptin $100 \mathrm{nM}$ response, Fig. 2a). However, bumetanide at $20 \mu \mathrm{M}$ to block NKCC1 shifted $\mathrm{E}_{\mathrm{GABA}}$ toward hyperpolarizing values (from $-51.4 \pm 2.9(\mathrm{n}=20)$ to $-75.4 \pm 4.4 \mathrm{mV}$ $(\mathrm{n}=10), \mathrm{U}=23.5, p=0.009$, Fig. $2 \mathrm{~b})$ but failed to prevent the effect of leptin $\left(100 \mathrm{nM}, 20 \mathrm{~min}\right.$ ) on $\mathrm{E}_{\mathrm{GABA}}$ (from $-75.4 \pm 5.8$ to $-67.4 \pm 6.2 \mathrm{mV}, \mathrm{n}=7, \mathrm{z}=-2.1, p=0.04$, $\Delta \mathrm{E}_{\mathrm{GABA}}=8.2 \pm 2.9 \mathrm{mV}, \mathrm{U}=28, p=0.51$ vs leptin $100 \mathrm{nM}$ response, Fig. 2a). These results suggest that leptin down-regulates $\mathrm{KCC} 2$ activity. Accordingly, the selective KCC2 blocker VU0463271 $(20 \mu \mathrm{M})$ led to a non-significant depolarizing shift of $\mathrm{E}_{\mathrm{GABA}}$ (from $-57.5 \pm 6.1$ to $-42.3 \pm 4.0 \mathrm{mV}, \mathrm{n}=6, \mathrm{z}=-1.9, p=0.06$, Fig. $2 \mathrm{~b})$ and prevented the effect of leptin (100 nM, $20 \mathrm{~min}$ ) (from $-43.8 \pm 3.2$ to $-44.7 \pm 3.8 \mathrm{mV}, \mathrm{n}=7, \mathrm{z}=-0.6, P=0.65$, $\Delta \mathrm{E}_{\mathrm{GABA}}=-0.8 \pm 1.2 \mathrm{mV}, \mathrm{U}=9.5, p=0.01$ vs leptin $100 \mathrm{nM}$ response, Fig. 2a).

To determine whether the increase in spike firing induced by bath applied leptin (Fig. 1c, d) also resulted from a down regulation of $\mathrm{KCC} 2$ activity and a modification of GABAergic strength, the same experiment was repeated in the continuous presence of the selective $\mathrm{GABA}_{\mathrm{A}}$ receptor antagonist Gabazine $(5 \mu \mathrm{M})$ or in the presence of the selective KCC2 blocker VU0463271. We found that Gabazine $(5 \mu \mathrm{M})$ completely abolished
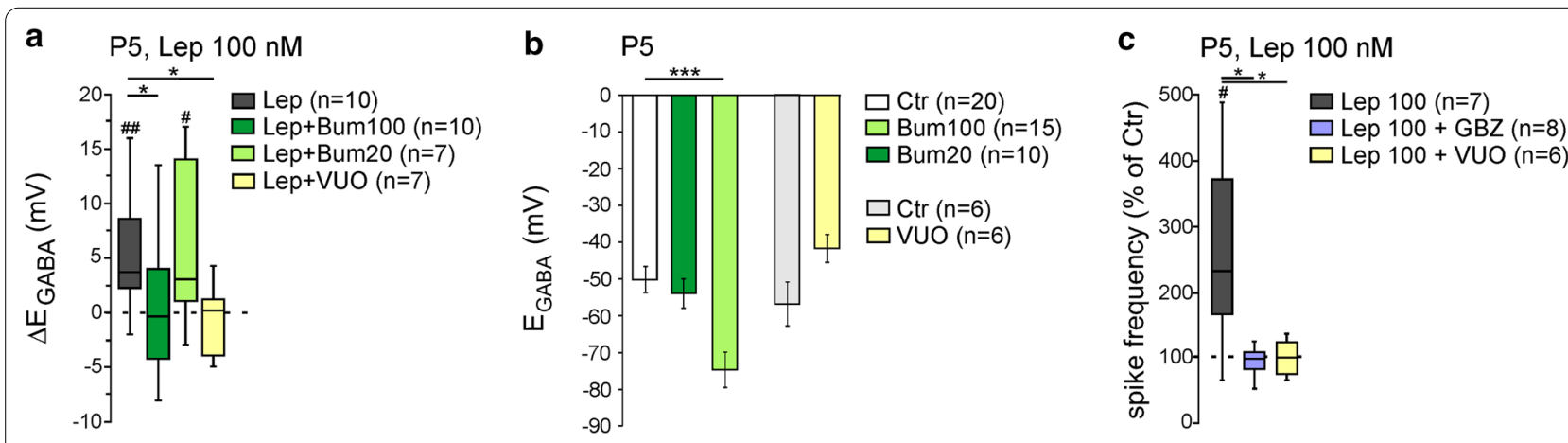

Fig. 2 Leptin controls KCC2 activity in rat hippocampal slices. a Box plots of $\triangle \mathrm{E}_{\mathrm{GABA}}$ induced by leptin $100 \mathrm{nM}(20 \mathrm{~min})$ in control condition (Lep), in the presence of bumetanide 100 and $20 \mu \mathrm{M}$, or in the presence of VU0423271 (VU0, $10 \mu \mathrm{M})$. $\mathbf{b}$ Bar plots of the mean and standard error to the mean of the reversal potential of $\mathrm{GABA}_{A}$ receptor-mediated postsynaptic currents $\left(\mathrm{E}_{\mathrm{GABA}}\right)$ in the indicated conditions. $\mathbf{c}$ Box plots of leptin action (100 nm,

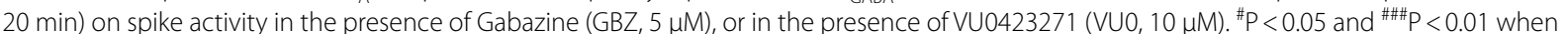
compared to pre-leptin values, two-tailed Wilcoxon paired test. ${ }^{*} \mathrm{P}<0.05$ and ${ }^{* * *} \mathrm{P}<0.001$ when compared to leptin experiments, two-tailed Mann Whitney test 
the leptin-induced (100 $\mathrm{nM}, 20 \mathrm{~min}$ ) increase in firing. The frequency of action potential was respectively $0.81 \pm 0.22 \mathrm{~Hz}$ and $0.85 \pm 0.28 \mathrm{~Hz}$ before and during the application of leptin $(\mathrm{n}=8, \mathrm{z}=-0.07, p=0.96$ vs baseline and $\mathrm{U}=7, p=0.01$ vs leptin $100 \mathrm{nM}$ response, Fig. 2c). Likewise, the selective KCC2 blocker VU0463271 $(20 \mu \mathrm{M})$ also prevented the effect of leptin (100 nM, $20 \mathrm{~min}$ ) (from $0.23 \pm 0.06$ to $0.21 \pm 0.04 \mathrm{~Hz}$ before and during the application of leptin, $\mathrm{n}=6, \mathrm{z}=-0.4, p=0.72$ vs baseline and $\mathrm{U}=6, p=0.03$ vs leptin $100 \mathrm{nM}$ response, Fig. 2c). Altogether, these data show that leptin downregulates $\mathrm{KCC} 2$ activity shifting $\mathrm{E}_{\mathrm{GABA}}$ towards depolarizing values in $\mathrm{P} 5$ rat hippocampal slices.

\section{The action of leptin in vitro on chloride homeostasis is developmentally regulated}

Previous studies reported that the responsiveness of leptin is regulated during development [29, 35-37]. We therefore asked whether the leptin-induced depolarizing shift of $\mathrm{E}_{\mathrm{GABA}}$ is developmentally regulated. We found a non-linear bell-shaped relationship between the age of the rats and the responsiveness of leptin. Thus, while bath applied leptin (100 $\mathrm{nM}, 20 \mathrm{~min})$ led to a significant depolarizing shift of $\mathrm{E}_{\mathrm{GABA}}$ at P5 (Fig. 1b), the same application had no effect on the reversal potential of $\mathrm{GABA}_{\mathrm{A}}-\mathrm{PSCs}$ evoked on hippocampal slices at P2 (from $-45.6 \pm 7.1$ to $-47.6 \pm 6.4 \mathrm{mV}, \mathrm{n}=5, \mathrm{z}=-0.9$, $p=0.43, \Delta \mathrm{E}_{\mathrm{GABA}}=-0.7 \pm 2.1 \mathrm{mV}, U=7, P=0.02$ vs leptin $100 \mathrm{nM}$ response at P5, Fig. 3a) and P10 (from $-70.8 \pm 2.1$ to $-70.3 \pm 2.7 \mathrm{mV}, \mathrm{n}=6, \mathrm{z}=-0.1, p=0.99$, $\Delta \mathrm{E}_{\mathrm{GABA}}=0.5 \pm 1.6 \mathrm{mV}, \mathrm{U}=14, p=0.08$ vs leptin $100 \mathrm{nM}$ response at P5, Fig. 3a). Of note, the effect of leptin on $\mathrm{E}_{\mathrm{GABA}}$ was not correlated to the initial polarity of the GABAergic responses (Fig. 3b). Likewise, leptin (100 nM,
$20 \mathrm{~min}$ ) failed to increase the firing frequency of CA3 pyramidal neurons when applied at $\mathrm{P} 10$ (from $0.55 \pm 0.13$ to $0.64 \pm 0.13 \mathrm{~Hz}$ before and during the application of leptin, $\mathrm{n}=11, \mathrm{z}=-1.8, p=0.1$ and $\mathrm{U}=16, p=0.9$ vs baseline leptin $100 \mathrm{nM}$ response at P5, Fig. 3c). We were unable to test the effect of leptin at P2 because of a sparse action potentials and low frequency discharge. Altogether, these data show that the effects of leptin on chloride homeostasis in vitro are restricted to a narrowed developmental window.

\section{Discussion}

Besides its key role in regulating energy balance, leptin exerts many other important developmental and physiological functions throughout life [1, 2, 4, 7, 38]. In the present study, we show that leptin acts directly on newborn rat hippocampal neurons to control the chloride homeostasis and the strength of GABAergic inhibition in vitro. We further show that the effects of leptin rely on the control of the activity of the $\mathrm{K} / \mathrm{Cl}$ cotransporter KCC2 and are present during a restricted developmental window. The present study complements previous reports of leptin modulating GABAergic synaptic transmission in the developing rat hippocampus in vitro [12, 29] and extends our previous report of leptin controlling the ontogenesis of functional GABAergic inhibition in the developing mice hippocampus in vivo [13].

Our data demonstrate that bath applied leptin regulates the activity of $\mathrm{KCC} 2$ in the developing rat hippocampus. We have shown that leptin treatment induces a depolarizing shift of $E_{G A B A}$ and increases the firing frequency of CA3 pyramidal neurons. Both effects were prevented by the selective KCC2 blocker VU0463271. How acute (20 min) application of leptin controls KCC2 activity is

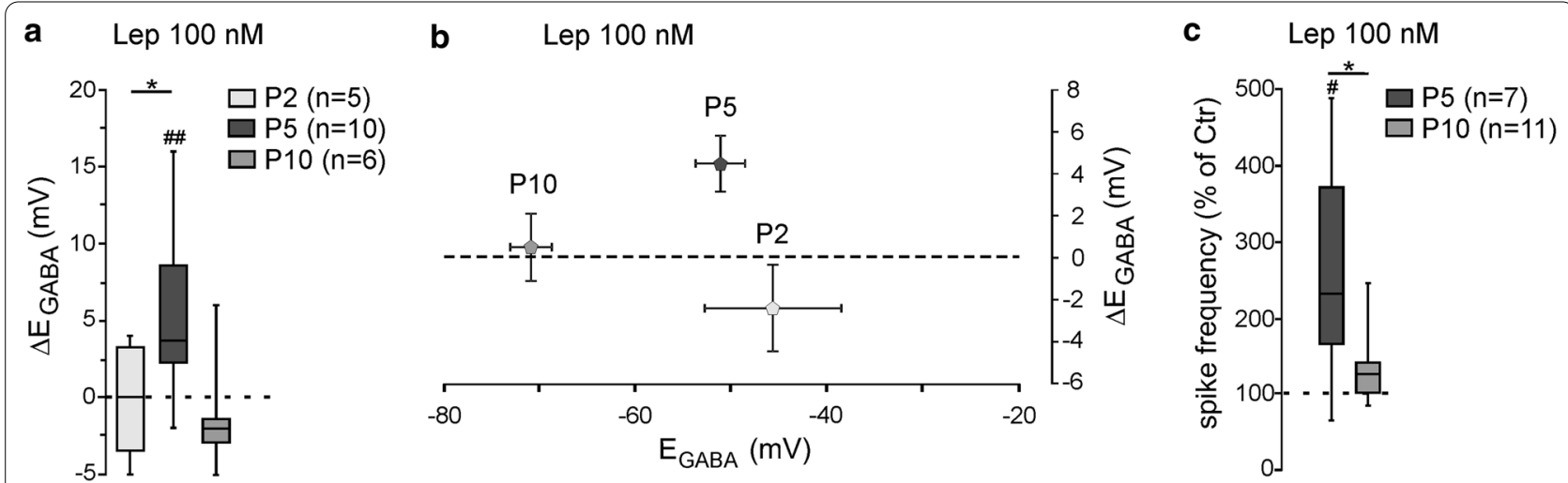

Fig. 3 The action of leptin of chloride homeostasis is developmentally regulated. a Box plots of $\triangle E_{G A B A}$ induced by leptin (100 nM, $\left.20 \mathrm{~min}\right)$ at postnatal $(P)$ day 2, 5 and 10. b Plots of mean and standard error to the mean of the $\triangle E_{G A B A}$ induced by leptin (100 nM, 20 min) versus the reversal potential of $G_{A B A_{A}}$ receptor-mediated postsynaptic currents ( $\left.E_{G A B A}\right)$ at P2, P5 and P10. c Box plots of leptin action (100 nM, 20 min) on spike activity at P5 and P10. ${ }^{\# P}<0.05$ when compared to pre-leptin values, two-tailed Wilcoxon paired test. ${ }^{*} \mathrm{P}<0.05$ when compared to leptin response at P5, two-tailed Mann Whitney test 
presently unknown. The ion transport activity of KCC2 depends on transcriptional factors (i.e. the protein abundance) as well as post-translational regulations by (de) phosphorylation of the protein [33, 34]. We previously showed that newborn leptin receptor deficient $(d b / d b)$ mice showed an increased expression of KCC2 compared to their wild type littermates [13]. We also showed that chronic $(24 \mathrm{~h})$ treatment of rat hippocampal neuronal cultures with leptin decreased the amount of KCC2 and increased the phosphorylation of the threonine 906 and 1007 residues (Thr906/Thr1007) of KCC2 [13], known to decrease the membrane expression and activity of the transporter $[39,40]$. In the presence study, the acute (20 min) application of leptin was unlikely to induce transcriptional modifications, and a post-translational regulation is the most expected mechanism to account for the reduced activity of $\mathrm{KCC} 2$.

Developmental changes in leptin's actions and downstream signaling pathways have been reported in the hippocampus $[29,35,37]$ and hypothalamus [36]. We found that the effects of an acute $(20 \mathrm{~min})$ leptin $(100 \mathrm{nM})$ application on $\mathrm{E}_{\mathrm{GABA}}$ and firing of $\mathrm{CA} 3$ pyramidal neurons are also developmentally regulated been observed at P5 but not at P2 and P10 on rat hippocampal slices. We previously reported that a chronic $(24 \mathrm{~h})$ leptin $(100 \mathrm{nM})$-treatment had no effect on immature rat hippocampal neurons (DIV6), when KCC2 activity is low, but led to a depolarizing shift of $\mathrm{E}_{\mathrm{GABA}}$ in more mature cultures (DIV15), when GABA had shifted to hyperpolarized values [13]. Differences in experimental systems and/or treatment protocols are possible explanations for the difference in leptin's action in neuronal cultures versus acute slices at a time when the developmental shift of GABAergic responses had occurred (i.e. at DIV15 and P10 respectively). However, our observation that an acute application of leptin (100 nM, $20 \mathrm{~min}$ ) induced a depolarizing shift of $\mathrm{E}_{\mathrm{GABA}}$ in DIV15 neuronal cultures (unpublished observation) strongly suggest that differences in experimental system is the most likely explanation.

Different mechanisms, including a developmentally regulated expression of the leptin receptors as well as downstream signaling pathways and/or effectors could account for the developmental changes in leptin's actions observed in hippocampal slices. The former hypothesis is unlikely since both molecular $[8,10]$ and functional $[11,12]$ studies revealed the presence of functional leptin receptors in the newborn rodent hippocampus. Accordingly, real-time qRT-PCR revealed the presence of Leptin receptor transcript in rat hippocampi at P2, P5 and P10 (unpublished observation). The latter hypothesis could be considered even if the downstream pathway linking leptin and the activity of $\mathrm{KCC} 2$ remains to be elucidated. The With No lysine family of serine/threonine kinase
(WNK)-dependent phosphorylation of the Thr906/ Thr1007 residues of KCC2 is a key player in the regulation of chloride homeostasis during development [39, 40]. We previously obtained evidence that a chronic leptin-treatment $(24 \mathrm{~h})$ promotes the phosphorylation of the Thr906/Thr1007 residues of KCC2 via a WNK-dependent pathway on hippocampal neuronal cultures [13]. Developmental changes in WNK signaling and WNK-dependent control of chloride homeostasis have been observed both in vitro and in vivo in cortical and hippocampal neurons [39, 40]. Moreover, Thr906/Thr1007 residues becomes progressively dephosphorylated during neuronal development $[40,41]$. Thus, the high level of endogenous Thr906/Thr1007 phosphorylated KCC2 at birth and the absence of KCC2-dependent control of chloride homeostasis by endogenous WNK in mature neurons are possible explanations for the restricted effects of leptin.

A variety of factors control the activity of $\mathrm{KCC} 2$ and/ or NKCC1 (for review see [42]). Among this array of factors, Neurturin, BDNF and oxytocin also displayed specific age-dependent actions on KCC2. Neurturin promotes the activity of KCC2 in hippocampal neuronal cultures [43]. This facilitatory effect peaked at DIV11 and declined with neuronal culture maturation, likely as a consequence of corresponding receptors expression. The effect of BDNF on KCC2 encompasses up regulation in immatures neuronal cultures [44] and down regulation in matures neuronal cultures [45] as a consequence of a change in the BDNF-receptor activated pathway [45]. Finally, oxytocin increases the membrane expression/ stabilization of KCC2 during a very narrow time window (i.e. DIV3 and DIV4) in hippocampal neuronal cultures, but induced no significant change at DIV5 and a reduction at DIV6, most likely as a developmental change in oxytocin receptor activated pathway [46].

We have shown that an acute elevated concentration (i.e. $100 \mathrm{nM}$, but not $20 \mathrm{nM}$ ) of leptin affects the chloride homeostasis of the CA3 pyramidal neurons on newborn rat hippocampal slices. Likewise, in a previous study we reported that chronic hyperleptinemia, induced in vivo by daily sub-cutaneous injections of leptin from P2 to P10, delayed the emergence of functional GABAergic inhibition in the newborn mice hippocampus [13], while the same injections from P20 to P30 has no effect on GABAergic inhibition (unpublished observation). Elevated circulating leptin levels have been observed in patient with neurodevelopmental disorders such as Autistic spectrum disorder (ASD) and Rett syndrome $[15,16,18,46,47]$ and in animal models of the diseases $[48,49]$. Moreover, accumulating evidence indicate that impaired chloride homeostasis is a common feature of numerous neurological disorders associated with impairments in hippocampal-dependent cognitive processes 
[30-32]. Although translating animal research to the human situation is difficult, the developmental window of the actions of elevated leptin levels on GABAergic inhibition in vivo and in vitro is consistent with a possible role of elevated leptin levels in neurodevelopmental disorders. Targeting the leptin signaling pathway may therefore have therapeutic potential in neurological and neuropsychiatric disorders.

\begin{abstract}
Abbreviations
APV: 5-Amino-phosphono-valeric acid; ASD: Autistic spectrum disorder; $d b / d b$ mice: Leptin-receptor deficient mice; BDNT: Brain-derived neurotrophic factor; eGABA $A_{A}-P S C s$ : Evoked GABA receptor-mediated postsynaptic currents; DIV: Days in vitro; GABA: $\gamma$-Aminobutyric acid; $\mathrm{KCC} 2 \mathrm{~K}^{+}-\mathrm{Cl}^{-}$cotransporter; $\mathrm{NBQX}$ : 1,2,3,4-Tetrahydro-6-nitro-2,3-dioxo-benzo[f]quinoxaline-7-sulfonamide; NKCC1: $\mathrm{Na}^{+}-\mathrm{K}^{+}-2 \mathrm{Cl}^{-}$co-transporter; ob/ob mice: Leptin deficient mice; Thr906/Thr1007: Threonine 906 and 1007 residues; WNK: With no lysine family of serine/threonine kinase.
\end{abstract}

\section{Authors' contributions}

$J \mathrm{LG}, \mathrm{GW}, \mathrm{SA}$ and CD conceived and designed the experiments. CD, YB and DD performed the experiments and analyzed the data. JLG drafted the manuscript and all authors participated in critical revision of the manuscript. All authors approved the final version of the manuscript. All authors read and approved the final manuscript.

\section{Funding}

This work was supported by the French Ministry of Education (MRT) to CD; the National Institutes of Health (Grant HD092396) to G.W and JLG; and the Association Française du syndrome de Rett to JLG. The project leading to this publication has received funding from the Excellence Initiative of Aix-Marseille University-A*midex, a french "Investissements d'Avenir programme", MarMara AMX-19-IET-007.

\section{Availability of data and materials}

The data sets generated for this study are available from the corresponding author upon reasonable request.

\section{Ethics approval and consent to participate}

All animal procedures were carried out in accordance with the European Union Directive of 22 September (2010/63/EU). The protocol was approved by the INSERM Local committee (Number 0287.01, delivered by the French Ministry of Education and Research).

\section{Consent for publication}

Not applicable.

\section{Competing interests}

The authors declare that they have no competing interests.

\section{Author details}

${ }^{1}$ Aix-Marseille Univ UMR 1249, INSERM (Institut National de La Santé et de La Recherche Médicale) Unité 1249, INMED (Institut de Neurobiologie de La Méditerranée), Parc Scientifique de Luminy, Marseille, France. ${ }^{2}$ Program in Neuroscience, Department of Integrative Physiology and Neuroscience, Washington State University, Pullman, WA, USA. ${ }^{3}$ Present Address: Neurochlore Parc Scientifique et Technologique de Luminy, Bâtiment Beret Delaage, Zone Luminy Entreprises Biotech, Marseille, France.

Received: 30 June 2020 Accepted: 28 October 2020

Published online: 12 November 2020

\section{References}

1. Ahima RS, Flier JS. Leptin. Annu Rev Physiol. 2000;62(1):413-37.
2. Harvey J. Leptin regulation of neuronal excitability and cognitive function. Curr Opin Pharmacol. 2007;7(6):643-7.

3. McGregor G, Harvey J. Regulation of hippocampal synaptic function by the metabolic hormone, leptin: implications for health and neurodegenerative disease. Front Cell Neurosci. 2018;12:340.

4. Bouret SG. Organizational actions of metabolic hormones. Front Neuroendocrinol. 2013;34(1):18-26.

5. Harvey J. Leptin regulation of neuronal morphology and hippocampal synaptic function. Front Synaptic Neurosci. 2013;5:3.

6. Briffa JF, McAinch AJ, Romano T, Wlodek ME, Hryciw DH. Leptin in pregnancy and development: a contributor to adulthood disease? Am J Physiol Endocrinol Metab. 2015;308(5):E335-350.

7. Valleau JC, Sullivan EL. The impact of leptin on perinatal development and psychopathology. J Chem Neuroanat. 2014;61-62:221-32.

8. Carlo A-S, Meyerhof W, Williams LM. Early developmental expression of leptin receptor gene and [125I]leptin binding in the rat forebrain. J Chem Neuroanat. 2007;33(3):155-63.

9. Pan W, Hsuchou H, Tu H, Kastin AJ. Developmental changes of leptin receptors in cerebral microvessels: unexpected relation to leptin transport. Endocrinology. 2008;149(3):877-85.

10. Caron E, Sachot C, Prevot V, Bouret SG. Distribution of leptin-sensitive cells in the postnatal and adult mouse brain. J Comp Neurol. 2010;518(4):459-76.

11. Dhar M, Wayman GA, Zhu M, Lambert TJ, Davare MA, Appleyard SM. Leptin-induced spine formation requires TrpC channels and the CaM kinase cascade in the hippocampus. J Neurosci. 2014;34(30):10022-33.

12. Guimond D, Diabira D, Porcher C, Bader F, Ferrand N, Zhu M, et al. Leptin potentiates GABAergic synaptic transmission in the developing rodent hippocampus. Front Cell Neurosci. 2014;8:235.

13. Dumon C, Diabira D, Chudotvorova I, Bader F, Sahin S, Zhang J, et al. The adipocyte hormone leptin sets the emergence of hippocampal inhibition in mice. eLife. 2018;7:e36726.

14. Bland T, Zhu M, Dillon C, Sahin GS, Rodriguez-Llamas JL, Appleyard SM, et al. Leptin controls glutamatergic synaptogenesis and NMDA-receptor trafficking via fyn kinase regulation of NR2B. Endocrinology. 2020. https://doi.org/10.1210/endocr/bqz030.

15. Acampa M, Guideri F, Hayek J, Blardi P, De Lalla A, Zappella M, et al. Sympathetic overactivity and plasma leptin levels in Rett syndrome. Neurosci Lett. 2008;432(1):69-72.

16. Magge SN, O'Neill KL, Shults J, Stallings VA, Stettler N. Leptin levels among prepubertal children with Down syndrome compared with their siblings. J Pediatr. 2008;152(3):321-6.

17. Agar $E$. The role of cannabinoids and leptin in neurological diseases. Acta Neurol Scand. 2015;132(6):371-80.

18. Lisik MZ, Gutmajster E, Sieroń AL. plasma levels of leptin and adiponectin in fragile $X$ syndrome. NeurolmmunoModulation. 2016;23(4):239-43.

19. Signore AP, Zhang F, Weng Z, Gao Y, Chen J. Leptin neuroprotection in the CNS: mechanisms and therapeutic potentials. J Neurochem. 2008;106(5):1977-90.

20. Fernández-Martos CM, González P, Rodriguez FJ. Acute leptin treatment enhances functional recovery after spinal cord injury. PLoS ONE. 2012:7(4):e35594.

21. Garza JC, Guo M, Zhang W, Lu X-Y. Leptin restores adult hippocampal neurogenesis in a chronic unpredictable stress model of depression and reverses glucocorticoid-induced inhibition of GSK-3 $\beta / \beta$-catenin signaling. Mol Psychiatry. 2012;17(8):790-808.

22. Li L-L, Li Y-C, Zhao D-J, Jin M-F, Ni H. Leptin-regulated autophagy plays a role in long-term neurobehavioral injury after neonatal seizures and the regulation of zinc/CPLA2 and CaMK II signaling in cerebral cortex. Epilepsy Res. 2018;146:103-11.

23. Ren J, Li X, Sun G, Li S, Liang S, Li Z, et al. Protective effect of leptinmediated caveolin-1 expression on neurons after spinal cord injury. Cell Calcium. 2018;76:122-8.

24. Cellot G, Cherubini E. GABAergic signaling as therapeutic target for autism spectrum disorders. Front Pediatr. 2014;2:70.

25. Deidda G, Bozarth IF, Cancedda L. Modulation of GABAergic transmission in development and neurodevelopmental disorders: investigating physiology and pathology to gain therapeutic perspectives. Front Cell Neurosci. 2014;8:119. 
26. Pinto S, Roseberry AG, Liu H, Diano S, Shanabrough M, Cai X, et al. Rapid rewiring of arcuate nucleus feeding circuits by leptin. Science. 2004;304(5667):11-5.

27. Cowley MA, Smart JL, Rubinstein M, Cerdán MG, Diano S, Horvath TL, et al. Leptin activates anorexigenic POMC neurons through a neural network in the arcuate nucleus. Nature. 2001;411(6836):480-4.

28. Münzberg H, Jobst EE, Bates SH, Jones J, Villanueva E, Leshan $\mathrm{R}$, et al. Appropriate inhibition of orexigenic hypothalamic arcuate nucleus neurons independently of leptin receptor/STAT3 signaling. J Neurosci. 2007;27(1):69-74.

29. Solovyova N, Moult PR, Milojkovic B, Lambert JJ, Harvey J. Bi-directional modulation of fast inhibitory synaptic transmission by leptin. J Neurochem. 2009;108(1):190-201.

30. Ben-Ari Y. NKCC1 chloride importer antagonists attenuate many neurological and psychiatric disorders. Trends Neurosci. 2017;40(9):536-54.

31. Moore YE, Kelley MR, Brandon NJ, Deeb TZ, Moss SJ. Seizing control of KCC2: a new therapeutic target for epilepsy. Trends Neurosci. 2017:40(9):555-71.

32. Kitayama T. The role of $\mathrm{K}+-\mathrm{Cl}-$ cotransporter- 2 in neuropathic pain. Neurochem Res. 2018:43(1):110-5

33. Kahle KT, Deeb TZ, Puskarjov M, Silayeva L, Liang B, Kaila K, et al. Modulation of neuronal activity by phosphorylation of the $\mathrm{K}-\mathrm{Cl}$ cotransporter KCC2. Trends Neurosci. 2013;36(12):726-37.

34. Medina I, Friedel P, Rivera C, Kahle KT, Kourdougli N, Uvarov P, et al. Current view on the functional regulation of the neuronal $\mathrm{K}(+)-\mathrm{Cl}(-)$ cotransporter KCC2. Front Cell Neurosci. 2014;8:27.

35. Moult PR, Harvey J. NMDA receptor subunit composition determines the polarity of leptin-induced synaptic plasticity. Neuropharmacology. 2011;61(5-6):92436.

36. Baquero AF, de Solis AJ, Lindsley SR, Kirigiti MA, Smith MS, Cowley MA, et al. Developmental switch of leptin signaling in arcuate nucleus neurons. J Neurosci. 2014;34(30):9982-94.

37. Dumon C, Pisella L, Diabira D, Belaidouni Y, Wayman GA, Gaiarsa J-L. Developmental switch of leptin action on network driven activity in the neonatal rat hippocampus. Front Cell Neurosci. 2019;13:254.

38. Guo M, Huang T-Y, Garza JC, Chua SC, Lu X-Y. Selective deletion of leptin receptors in adult hippocampus induces depression-related behaviours Int J Neuropsychopharmacol. 2013;16(4):857-67.

39. Inoue K, Furukawa T, Kumada T, Yamada J, Wang T, Inoue R, et al. Taurine inhibits $\mathrm{K}+-\mathrm{Cl}$ - cotransporter $\mathrm{KCC} 2$ to regulate embryonic $\mathrm{Cl}$ - homeostasis via with-no-lysine (WNK) protein kinase signaling pathway. J Biol Chem. 2012;287(25):20839-50.
40. Friedel P, Kahle KT, Zhang J, Hertz N, Pisella LI, Buhler E, et al. WNK1-regulated inhibitory phosphorylation of the KCC2 cotransporter maintains the depolarizing action of GABA in immature neurons. Sci Signal. 2015;8(383):ra65.

41. Rinehart J, Maksimova YD, Tanis JE, Stone KL, Hodson CA, Zhang J, et al. Sites of regulated phosphorylation that control K-Cl cotransporter activity. Cell. 2009;138(3):525-36.

42. Watanabe M, Fukuda A. Development and regulation of chloride homeostasis in the central nervous system. Front Cell Neurosci. 2015;9:371.

43. Ludwig A, Uvarov P, Pellegrino C, Thomas-Crusells J, Schuchmann S, Saarma M, et al. Neurturin evokes MAPK-dependent upregulation of Egr4 and KCC2 in developing neurons. Neural Plast. 2011;2011:1-8.

44. Ludwig A, Uvarov P, Soni S, Thomas-Crusells J, Airaksinen MS, Rivera C. Early growth response 4 mediates BDNF induction of potassium chloride cotransporter 2 transcription. J Neurosci. 2011;31(2):644-9.

45. Rivera C, Voipio J, Thomas-Crusells J, Li H, Emri Z, Sipilä S, et al. Mechanism of activity-dependent downregulation of the neuron-specific $\mathrm{K}-\mathrm{Cl}$ cotransporter KCC2. J Neurosci. 2004;24(19):4683-91.

46. Leonzino M, Busnelli M, Antonucci F, Verderio C, Mazzanti M, Chini B. The timing of the excitatory-to-inhibitory GABA switch is regulated by the oxytocin receptor via KCC2. Cell Rep. 2016;15(1):96-103.

47. Ashwood P, Kwong C, Hansen R, Hertz-Picciotto I, Croen L, Krakowiak P, et al. Brief report: plasma leptin levels are elevated in autism: association with early onset phenotype? J Autism Dev Disord. 2008;38(1):169-75.

48. Blardi P, de Lalla A, D’Ambrogio T, Vonella G, Ceccatelli L, Auteri A, et al. Long-term plasma levels of leptin and adiponectin in Rett syndrome. Clin Endocrinol (Oxf). 2009;70(5):706-9.

49. Park MJ, Aja S, Li Q, Degano AL, Penati J, Zhuo J, et al. Anaplerotic triheptanoin diet enhances mitochondrial substrate use to remodel the metabolome and improve lifespan, motor function, and sociability in MeCP2-null mice. PLoS ONE. 2014;9(10):e109527.

50. Torres-Andrade R, Moldenhauer R, Gutierrez-Bertín N, Soto-Covasich J, Mancilla-Medina C, Ehrenfeld C, et al. The increase in body weight induced by lack of methyl $\mathrm{CpG}$ binding protein- 2 is associated with altered leptin signalling in the hypothalamus. Exp Physiol. 2014;99(9):1229-40.

\section{Publisher's Note}

Springer Nature remains neutral with regard to jurisdictional claims in published maps and institutional affiliations.
Ready to submit your research? Choose BMC and benefit from:

- fast, convenient online submission

- thorough peer review by experienced researchers in your field

- rapid publication on acceptance

- support for research data, including large and complex data types

- gold Open Access which fosters wider collaboration and increased citations

- maximum visibility for your research: over 100M website views per year

At BMC, research is always in progress.

Learn more biomedcentral.com/submissions 